\title{
ZHODNOTENIE STAVU STROPNÝCH PANELOV V AGRESÍVNOM PROSTREDÍ
}

\author{
CONDITION EVALUATION OF CEILING PANELS IN AN AGGRESSIVE \\ EN VIRONMENT
}

Ing. Hegedüsová Iveta, Ph.D., doc. Ing. Priganc Sergej, Ph.D.

\begin{abstract}
ABSTRAKT
V článku sú prezentované výsledky chemickej analýzy betónových vzoriek odobratých z existujúcich stropných panelov. Panely sú súčast'ou nosného systému pol'nohospodárskeho ustajňovacieho objektu. Analýza sa previedla za účelom preukázania nepriaznivého vplyvu agresívneho prostredia na betónovú nosnú konštrukciu.
\end{abstract}

\section{Klúčové slová:}

Stropný panel, degradácia, chemická analýza, obsah chloridových iónov, karbonatácia

\section{ABSTRACT}

The article presents chemical analysis results of concrete samples withdrawn from actual ceiling panels. The panels are a part of a load-bearing system of an agricultural farming structure. The analysis has been carried out to prove an unfavourable impact of the aggressive environment onto the bearing structure.

Key words: Ceiling panel, degradation, chemical analysis, chloride ion content, carbonation

\section{1 ÚVOD}

Pol'nohospodárske objekty na Slovensku, ktoré boli budované v 60 - tych rokoch minulého storočia, v súčasnosti vykazujú vysoký stupeň degradácie. V období intenzívneho rozvoja výstavby vel'kokapacitných kravínov normy, ktoré boli $\mathrm{v}$ platnosti, len $\mathrm{v}$ malej miere zohladňovali vplyv nepriaznivého prostredia na nosný železobetónový prvok. Z dôvodu nedostatku poznatkov o nepriaznivých účinkoch špecifického maštal’ného agresívneho prostredia na nosný prvok dnes objekty živočíšnej výroby vykazujú značné poškodenie a následné oslabenie svojej nosnej funkcie. Maštal'né prostredie je prezentované najmä vysokou relatívnou vlhkost'ou, škodlivými plynmi, maštal'nými kyselinami, baktériami a plesňami. Ďalším dôvodom degradácie je fakt, že v minulosti sa týmto objektom z hl'adiska ich údržby nevenovala dostatočná pozornost', čo sa výrazne odrazilo na znížení ich funkčnosti. Tento problém sa dotýka niekol'ko stoviek objektov, ktoré boli postavené na území celého Slovenska a ktoré dodnes slúžia na ustajnenie hovädzieho dobytka. Prevažná väššina z nich vykazuje vážne známky poškodenia, v najväčšej miere ide o degradáciu stropných panelov.

\section{SÚČASNÝ STAV STROPNÝCH PANELOV}

Na diagnostiku boli vybrané rebierkové vyl’ahčené železobetónové stropné panely s označením SZD 10n - 450 (Obr.1), ktoré boli montované v objektoch kravína typu K-174. Sú to extrémne vyl’ahčené prvky, ktoré boli $\mathrm{v}$ období ich výroby staticky spolahlivé. Vplyvom ich subtílnosti však došlo $\mathrm{k}$ degradácii ovel’a skôr, ako sa predpokladalo. Tieto stropné panely tvoria nosnú konštrukciu strechy kravína. Panel má šírku rebra $30 \mathrm{~mm}$ a hrúbku dosky $20 \mathrm{~mm}$. V pozdížnych rebrách je umiestnená 
hlavná nosná pozdížna výstuž (jeden profil s priemerom $8 \mathrm{~mm}$ ). Výstuž je kotvená v čelných rebrách súdržnost'ou alebo privarením k priečnym prútom (priemer $6 \mathrm{~mm}$ ) [1].

Obhliadka stropných panelov preukázala v podhl’adovej časti známky karbonatácie, čo malo za následok pokles ochrannej funkcie výstužných vložiek a výstuž začala korodovat'. Došlo k vzniku pozdížnych trhlín $\mathrm{v}$ rebrách $\mathrm{v}$ úrovni hlavnej nosnej výstuže. Pozdížne trhliny boli pozorované na prevažnej väčšine stropných panelov, navyše súdržnost' medzi výstužou a betónom bola bud' narušená alebo dokonca úplne zrušená. Betón bol miestami odpadnutý, teda krytie betónom neexistovalo, výstuž bola obnažená (Obr. 2). Následne bol meraný priemer tejto obnaženej výstuže, kritický úbytok prierezovej plochy zaznamenaný nebol. Obhliadka sa zamerala aj na zhodnotenie okrajových podmienok uloženia stropného panela, kde sa predpokladal vplyv agresívneho prostredia do vnútra kotviacej oblasti. V kritickej oblasti kotvenia trhliny neboli pozorované a preto zlyhanie panela z dôvodu porušenia v kotevnej oblasti sa nepredpokladá. Stropné panely boli obhliadnuté aj z pozície ich hornej hrany. Po odstránení jednotlivých vrstiev strešného plášt’a sa skonštatovalo, že pozorovaná zálievka bola sčasti porušená, miestami dokonca chýbala.

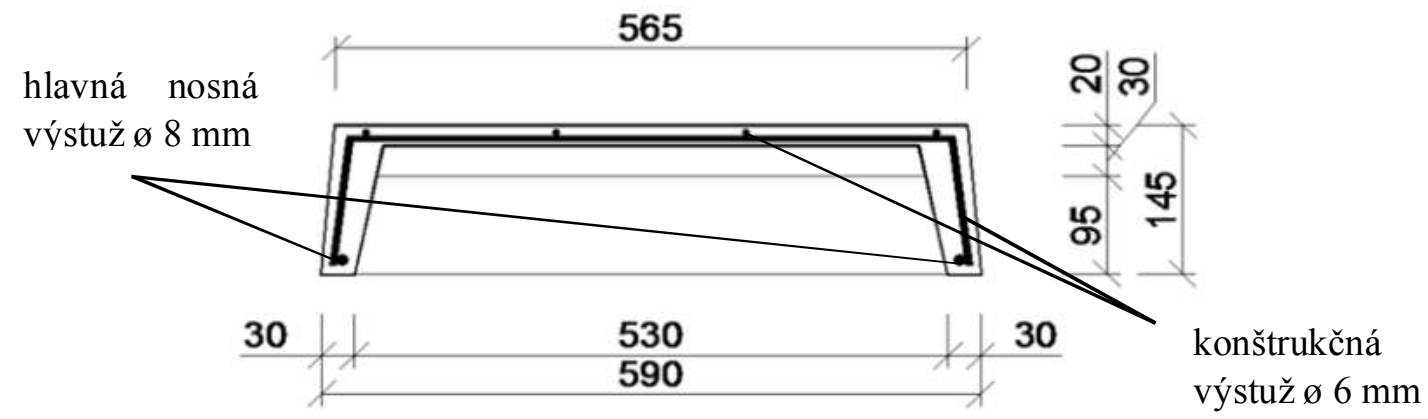

Obr. 1 Priečny rez panelom

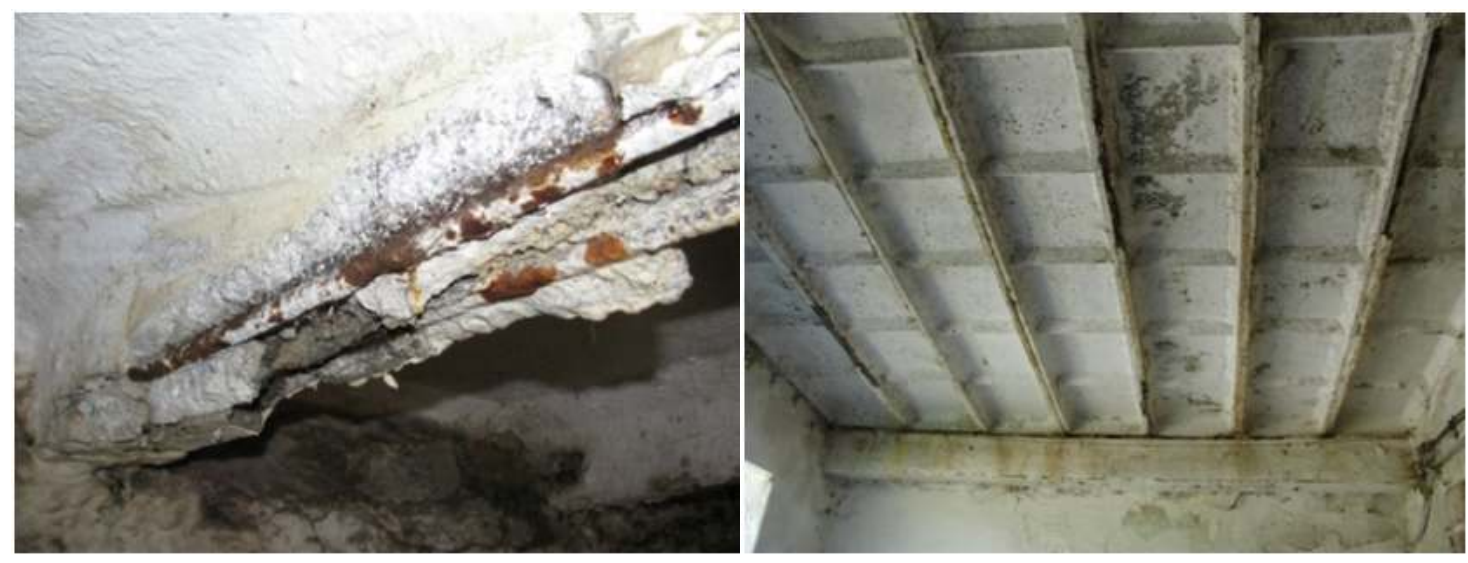

Obr. 2 Degradácia stropných panelov

V rámci obhliadky stropných panelov boli odobraté vzorky z troch najviac degradovaných stropných panelov (spolu 5 vzoriek). Vzorky boli prevezené do laboratória a podrobené chemickému rozboru. Chemický rozbor bol zameraný na zistenie obsahu škodlivých látok v betónovej konštrukcii (amónne soli, chloridové ióny, sírany, dusičnany) a alkalitu, vzhl’adom na dlhodobý vplyv agresívneho maštal'ného prostredia na stropné panely a následnú degradáciu týchto železobetonových prvkov. 


\section{CHEMICKÁ ANALÝZA}

Ciel’om chemickej analýzy bolo stanovit' zmeny alkalickej reakcie v prvom kroku semikvantitatívne fenolftaleínovým testom, vzorky sa následne spracovali a z pripravených výluhov sa stanovila alkalita na základe merania hodnôt $\mathrm{pH}$. Vzhl’adom na špecifické podmienky prostredia objektu K-174 sa v

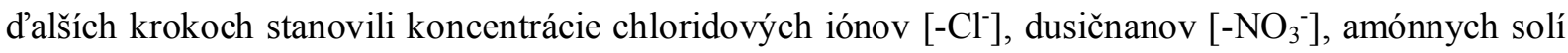
$\left[-\mathrm{NH}_{4}{ }^{+}\right]$. Súčasne sa vo vzorkách semikvantitatívne posudzovala aj prítomnost' síranov $\left[-\mathrm{SO}_{4}{ }^{2-}\right]$. Skúmané vzorky boli testované štandardnými postupmi za účelom získania poznatkov o obsahu škodlivých látok a to $\mathrm{z}$ dôvodu nepriaznivého vplyvu týchto látok na kvalitu betónu.

\subsection{Príprava vzoriek}

$\mathrm{K}$ dispozícii bolo 5 vzoriek z panelov, z každej vzorky sa čast' použila na fenolftaleínový test a zvyšok vzorky sa použil na pomletie v drvičke s označením BCD 32. Pomletá vzorka sa presypala na sústavu sít a preosiatím sa zabezpečila potrebná frakcia (jemné zrno s priemerom $0-0,5 \mathrm{~mm})(\mathrm{Obr} .3)$ $\mathrm{k}$ analýze. Do skúmaviek sa pomocou digitálnej váhy postupne navážili práškové vzorky o hmotnosti približne $2 \mathrm{~g}$. Každá vzorka sa zaliala $100 \mathrm{ml}$ deionizovanej vody a uzavrela sa fóliou, aby sa do skúmavky nedostali cudzie látky. Pripravené roztoky stáli v laboratóriu 24 hodín, aby sa mohli vylúhovat' látky obsiahnuté v betónovom prášku.

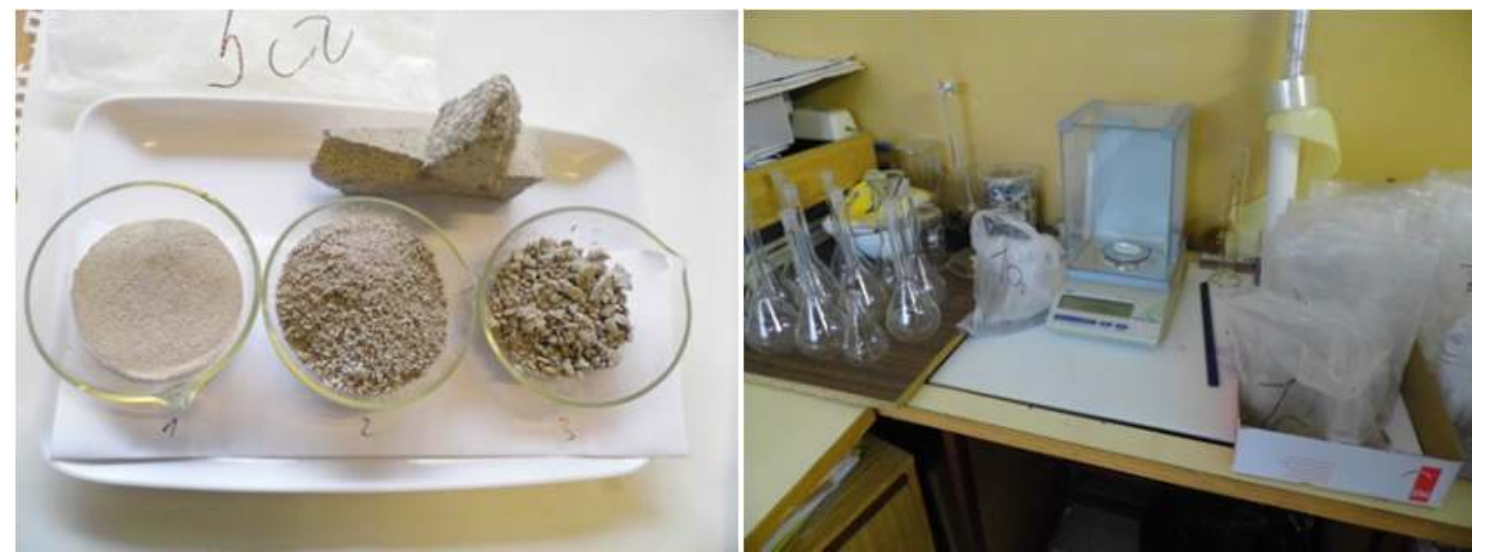

Obr. 3 Príprava roztokov ku skúškam

\subsection{Meranie vzoriek}

\subsubsection{Fenolftaleínový test}

Po nastriekaní fenolftaleínového roztoku na betónovú plochu vzoriek sa po hodine pôsobenia pozorovalo sfarbenie povrchu jednotlivých vzoriek. Podla [2] sa meria na rôznych miestach výška zafarbenia s presnostou na $1 \mathrm{~mm}$ pomocou híbkomeru a za výslednú hodnotu híbky karbonatácie sa pokladá priemerná hodnota z nameraných hodnôt. Na všetkých vzorkách bol test negatívny (Obr.4), čo svedčí o vysokom stupni karbonatácie.

\subsubsection{Meranie $\mathrm{pH}$ a obsahu chloridov}

Meranie hodnoty $\mathrm{pH}$ prebiehalo potenciometrickou metódou pomocou prístroja s označením $\mathrm{pH}$ meter MS 22, ktorý sa nakalibroval pomocou skúšobného roztoku na hodnotu 7,01. Do každej vzorky výluhu sa ponorili elektródy prístroja a z digitálneho displeya sa po ustálení odčítavala hodnota $\mathrm{pH}$. Meranie obsahu chloridových iónov sa uskutočnilo rovnakým prístrojom, ktorý sa opät nakalibroval a po výmene elektród sa rovnakým postupom meral elektrický potenciál (E) výluhu. 


\subsubsection{Meranie obsahu dusičnanov, síranov a amónnych solí}

Dusičnanový test a test na prítomnost' amónnych solí sa relizoval meracími súpravami pomocou činidla, rozsah merania sa pohyboval medzi $0 \mathrm{mg} / 1$ až $100 \mathrm{mg} / \mathrm{l}$. Po uplynutí časového limitu sa $\mathrm{v}$ roztoku rozvinula farba, ktorá sa porovnávala s priloženou farebnou stupnicou (Obr.4).
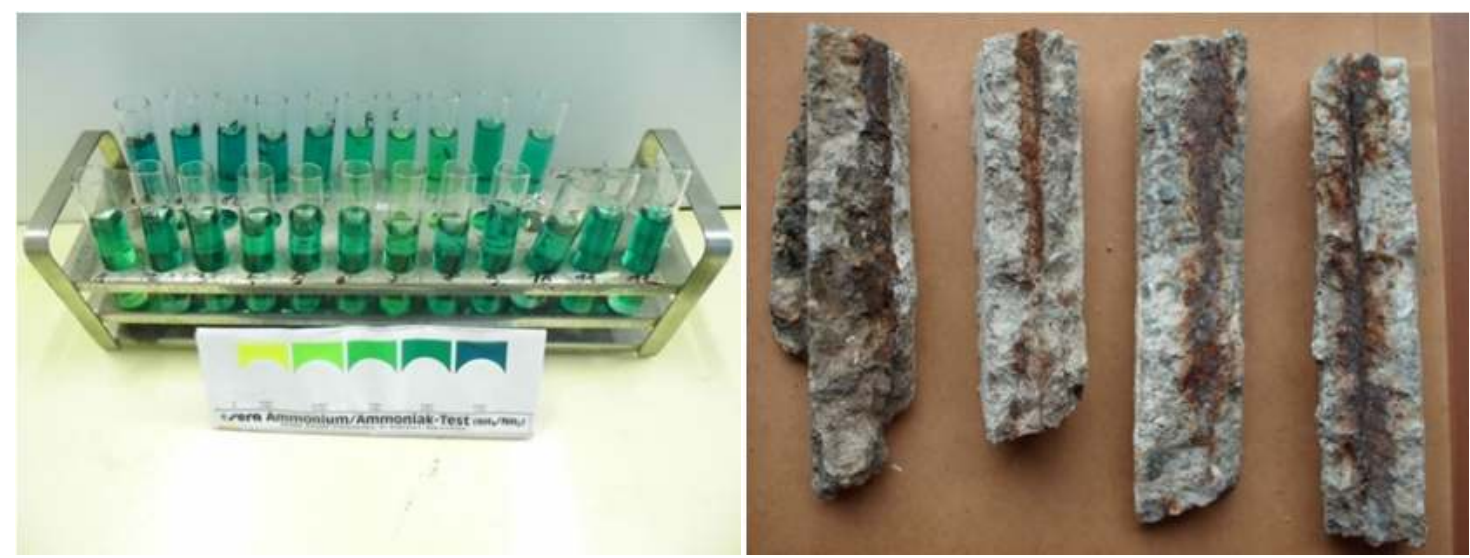

Obr. 4 Výsledky testu na prítomnost’ amónnych solí a fenolftaleínového testu

\subsubsection{Meranie obsahu síranov}

Síranový test sa realizoval semikvantitatívnou skúškou. Do výluhu sa pridal $10 \%$ - tný vodný roztok chlorovodíka $\mathrm{HCl}$ a roztok chloridu bárnatého $\mathrm{BaCl}_{2}$. Na základe intenzity bielej zrazeniny sa určila pozitívna reakcia, odstupňovaná podl’a množstva bieleho zákalu v skúmavke.

Po ukončení chemických skúšok sa namerané hodnoty spracovali, koncentrácie uvedené v mg/l sa prepočítali na percentuálny obsah a výsledky sa zaznamenali v Tab. 1 a na Obr. 5.

\begin{tabular}{|c|c|c|c|c|c|}
\hline $\begin{array}{c}\text { Ozn. } \\
\text { vzorky }\end{array}$ & $\mathrm{pH}$ & $\mathrm{Cl}^{-}[\%]$ & $\mathrm{NO}_{3}^{-}[\%]$ & $\mathrm{SO}_{4}$ & $\mathrm{NH}_{4}^{+}[\%]$ \\
\hline 1 & 8,98 & 0,129 & 0,601 & +++ & 0,048 \\
\hline 2 & 8,72 & 0,044 & 0,600 & +++ & 0,060 \\
\hline 3 & 9,23 & 0,079 & 0,463 & +++ & 0,046 \\
\hline 4 & 8,95 & 0,035 & 0,245 & +++ & 0,049 \\
\hline 5 & 9,13 & 0,072 & 0,241 & +++ & 0,048 \\
\hline
\end{tabular}

Tab. 1 Výsledky skúšok

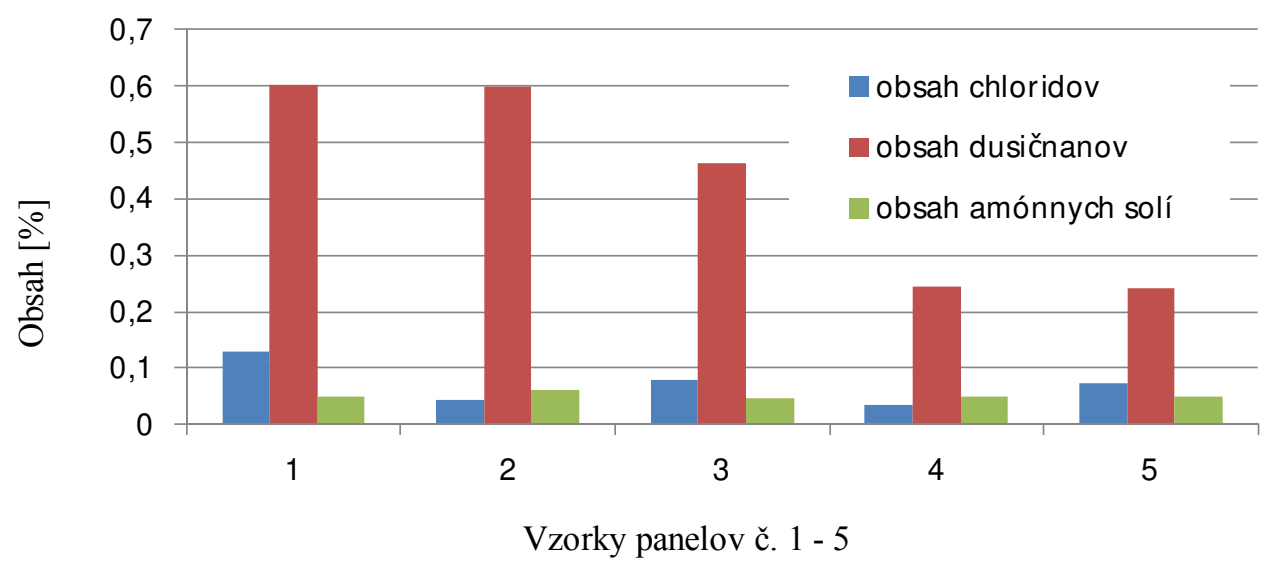

Obr. 5 Obsah chemických látok vo vzorkách panelov 


\section{VÝSLEDKY Z CHEMICKÉHO ROZBORU}

Z hl'adiska alkality (pH 8,72 - 9,23) bol najvyšší stupeň karbonatácie (III. stupeň) preukázaný u všetkých vzoriek, čo potvrdil aj fenolftaleínový test, ktorý bol u týchto vzoriek negatívny.

Z hl'adiska obsahu chloridových iónov možno skonštatovat', že u vzoriek stropných panelov bola preukázaná priemerná hodnota $0,072 \% \mathrm{Cl}^{-}$. Tieto percentuálne hodnoty sú vztiahnuté $\mathrm{k}$ hmotnosti betónu. Norma uvádza, že obsah chloridov $\mathrm{v}$ betóne, vyjadrený percentuálnym podielom $\mathrm{Cl}^{-}$iónov $\mathrm{k}$ hmotnosti cementu nesmie prekročit' hodnoty požadovanej kategórie podl'a Tab. 10 uvedenej v norme [3]. Pre betón s ocel'ovou výstužou platí kategória $\mathrm{Cl} 0,4$, pre ktorú je medzná hodnota $0,4 \% \mathrm{Cl}^{-}$. Priemerné hodnoty boli prepočítané a vztiahnuté k hmotnosti cementu a sú uvedené v Tab. 2.

\begin{tabular}{|c|c|c|c|c|}
\hline Ozn. vzorky & $\% \mathrm{Cl}^{-} / \mathrm{mb}$ & $\min . \% \mathrm{Cl}^{-} / \mathrm{mc}$ & $\operatorname{primer} \% \mathrm{Cl}^{-} / \mathrm{mc}$ & $\max .{ }^{\circ} \mathrm{Cl}^{-} / \mathrm{mc}$ \\
\hline 1 & 0,129 & 1,195 & 0,835 & 0,768 \\
\hline 2 & 0,044 & 0,407 & 0,319 & 0,262 \\
\hline 3 & 0,079 & 0,731 & 0,572 & 0,470 \\
\hline 4 & 0,035 & 0,324 & 0,254 & 0,208 \\
\hline 5 & 0,072 & 0,667 & 0,522 & 0,429 \\
\hline priemer & 0,072 & 0,665 & 0,520 & 0,423 \\
\hline
\end{tabular}

Tab. 2 Percentuálny obsah $\mathrm{Cl}^{-} \mathrm{k}$ hmotnosti betónu a cementu

Pôvodná receptúra betónovej zmesi nebola k dispozícii. Množstvá cementu pridávané do betónovej zmesi pri prefabrikátoch sa pohybovali v čase ich hromadnej výroby v intervale od 270 do $420 \mathrm{~kg} / \mathrm{m}^{3}$ v závislosti od typu prvku, od druhu kameniva a pod. Pre účel vyhodnotenia merania sa zvolili tri hodnoty obsahu cementu $\mathrm{v}$ betóne a to minimum, maximum a priemer $\mathrm{z}$ uvedených hodnôt, aby sa získala informatívna hodnota percentuálneho obsahu chloridových iónov vztiahnutá $\mathrm{k}$ hmotnosti cementu pre minimálne tri rôzne možné zámesi. Prítomnost' chloridových iónov $\mathrm{v}$ betóne nie je priaznivá skutočnost', ich vplyvom dochádza $\mathrm{k}$ bodovej korózii aj $\mathrm{v}$ zásaditom prostredí [4]. Pri vyšších koncentráciách sa treba obávat' výrazného úbytku prierezovej plochy výstuže, pretože ich migrácia do okolia výstuže urýchl'uje jej elektrochemickú koróziu a zároveň dochádza aj k degradácii betónu vplyvom kryštalizačných tlakov. Nameraný obsah chloridových iónov predstavuje pre stropné panely riziko (Obr. 6).

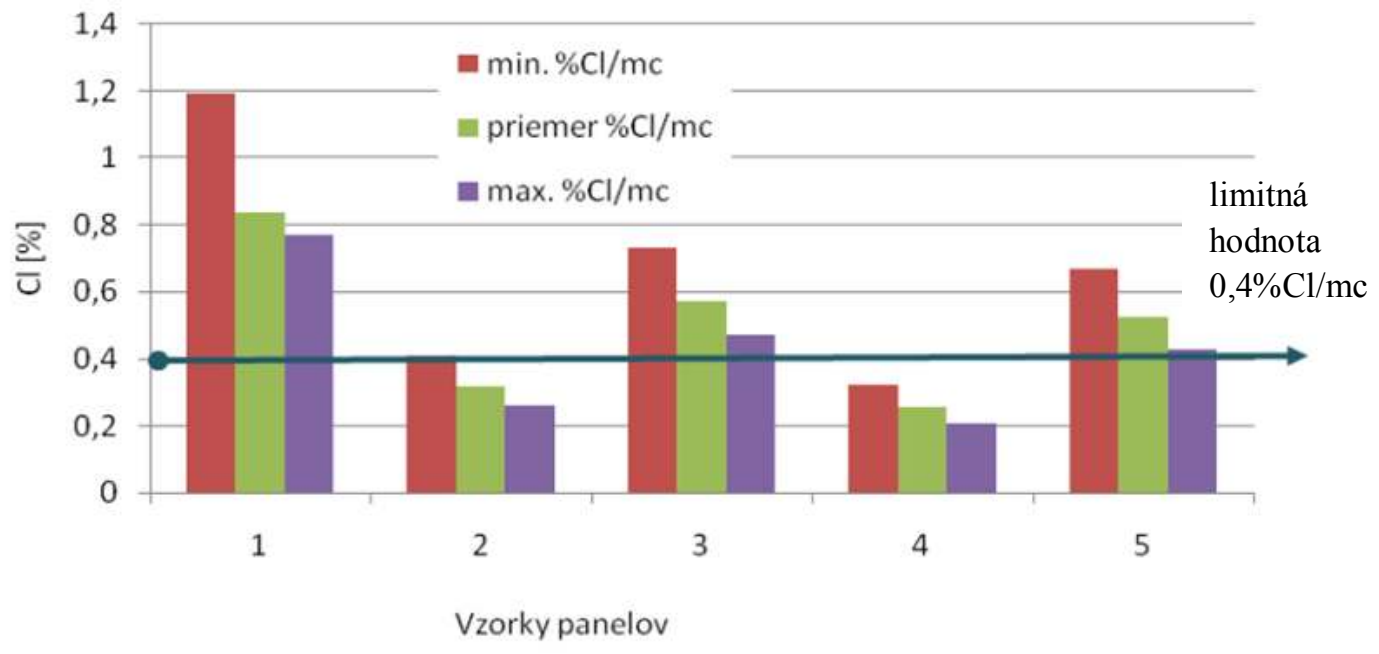

Obr. 6 Percentuálny obsah Cl- k hmotnosti cementu vo vzorkách 
Z hl'adiska koncentrácie síranových iónov u sledovaných vzoriek panelov bola zhodne preukázaná vel'mi silná pozitivita testu (+++). Možno predpokladat', že ide o vonkajšie chemické síranové napadnutie, spôsobené reakciou síranových iónov z vonkajších zdrojov so zložkami cementového kameňa.

Z hl'adiska koncentrácie dusičnanových iónov u sledovaných vzoriek panelov bola maximálna hodnota nameranej koncentrácie $0,601 \%\left(-\mathrm{NO}_{3}{ }^{-}\right)$. Dusičnany predstavujú pre betónovú konštrukciu nebezpečenstvo, pretože reakcia dusičnanu $\mathrm{s}$ hydroxidom vápenatým spôsobuje zväčšujúcu sa pórovitost' cementového kameňa a d’alšou postupnou reakciou dochádza $\mathrm{k}$ výraznému zväčšeniu objemu pevnej fázy [5]. Dochádza k degradácii štruktúry cementového kameňa.

Z hl'adiska koncentrácie amónnych solí bola u vzoriek panelov maximálna hodnota nameranej koncentrácie $0,060 \%\left(-\mathrm{NH}_{4}{ }^{+}\right), \mathrm{z}$ hl’adiska ohrozenia konštrukcie uvedené percentuálne množstvá nepredstavujú akútnu hrozbu.

\section{ZÁVER}

Z uvedených výsledkov vyplýva potreba dôkladne plánovat' zloženie betónovej zmesi pre betónové prvky, u ktorých je predpoklad, že budú zabudované v agresívnom prostredí. Ako uvádza norma [3] vplyv síranovej agresivity je nutné eliminovat' použitím cementov s vysokou síranovzdornostou (portlandský cement $\mathrm{s}$ obsahom $\mathrm{C}_{3} \mathrm{~A} v$ slinku menším ako $8 \%$ hmotnostných) a zároveň použitím prísad ako je kremičitý úlet alebo mletý zeolit. Z hl'adiska amónnej agresivity sa odporúča ako prísada taktiež kremičitý úlet a plastifikačná prísada.

Objekty vybudované v minulom storočí v súčasnosti nezodpovedajú dnešným požiadavkám noriem. Vyžadujú si dôslednú diagnostiku za účelom zhodnotenia ich stavu hlavne z hladiska statickej funkcie. Na základe týchto získaných informácií je možné správne určit typ rekonštrukčných prác, poprípade navrhnút' úplnú výmenu poškodených prvkov. Za účelom dôkladného zhodnotenia stavu betónových stropných panelov je potrebné k chemickej analýze doplnit' aj statické skúšky, zamerané na zist'ovanie priehybov stropných panelov a tieto merania je vhodné doplnit' aj numerickou analýzou, pomocou ktorej by bolo možné určit', či posudzovaný panel je alebo nie je schopný nad'alej plnit' svoju funkciu.

\section{Použitá literatura}

[1] Fecko, Ladislav a kol. Experimentálne overovanie únosnosti strešných železobetónových panelov z objektu K-174 v Hrabušiciach. KBaKK, VŠT Košice. Výskumná úloha R-02-529811. 1989.

[2] Matoušek, Milan; Drochytka, Rostislav. Atmosferická koroze betonu. Ikas Praha. 1998.

[3] STN EN 206-1.Betón. Čast’ 1: Špecifikácia, vlastnosti, výroba a zhoda. 2002.

[4] Bilč́́k, Juraj. Životnost' a trvanlivost', obnova panelových domov, komplexné riešenie konštrukčných, technologických, hygienických a energetických problémov. JPD 3/2004/4056, kód projektu 13120120137, Bratislava 6/2007. Európsky sociálny fond. http://www.4construction.com.

[5] Štefunková, Zuzana; Kmecová, Veronika. Vplyv roztokov dusičnanu amónneho na cementové pasty. Vidiecke stavby v európskych regiónoch II. Architektúra - konštrukcie technológie - bezpečnost' - logistika. Zborník recenzovaných vedeckých prác. SPU Nitra. 2014. ISBN 978-80-552-1242-5. 